\title{
The Effectiveness of Smart Learning Based on Expert Systems in Cryptography Courses
}

\author{
Moch. Iswan Perangin-angin ${ }^{1)}$, M. Syaifuddin²), Rian Farta Wijaya ${ }^{3)}$ \\ ${ }^{1,2}$ Management Informatica, STMIK Triguna Dharma, Jl. A. H Nasution No. 73 Medan Johor, Kota Medan \\ ${ }^{3}$ Computer Science, Universitas Pembangunan Pancabudi, Jl. Gatot Subroto No.Km.4, RW.5, Simpang Tj., Kec. Medan
} Sunggal - Kota Medan

\section{Article Info}

Article history:

Received 11 15, 2021

Revised 12 08, 2021

Accepted 12 20, 2021

\section{Keywords:}

Blended Learning

Project Based Learning

Cryptography

Security System

Development

\begin{abstract}
The development of science and technology requires universities not only to matter but also to have abilities in their respective fields including Security System. The unavailability of network design laboratory and its minimum, network design, cryptography design and flexibility of face-to-face time in the discussion of material compiled not in accordance with the competencies in this course. To overcome these deficiencies in learning activities, development of a project-based blended learning model is carried out. The development carried out in this study uses the Puslitjaknov development model which reduces the Borg and Gall stages to five stages namely product analysis, initial product design, expert validation and revision, field trials and implementation. Data were collected by interview, observation, questionnaire and test. Data were analyzed using quantitative and qualitative methods to produce research products in the form of books, modules, learning plans and manuals for the use of learning applications. Product validation by experts, practicality tests carried out by users and effectiveness tests with student learning outcomes. Based on the results of data analysis, the results of this study are: 1) Research has successfully developed a project-based blended learning model in Cryptography courses. 2) The developed learning model syntax consists of 9 stages / syntax. 3) In supporting learning activities, modules, RPS and manuals are used for learning applications. All products and models developed have been developed and are categorized as valid, practical and effective.
\end{abstract}

This is an open access article under the CC BY-SA license.

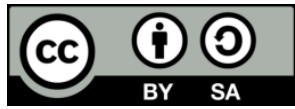

\section{Corresponding Author:}

Moch. Iswan Perangin-angin

Information Management, STMIK Triguna Dharma

Jln. A. H Nasution No. 73 Medan Johor, Medan, Indonesia

Email: mochammadiswan@gmail.com

(C) The Author(s) 2021

\section{INTRODUCTION}

Through education the development of potential, personality, intelligence, skills and noble character of students can be formed and directed. Each country has a legal system to regulate the educational process, launch educational standards, control the implementation phase and draw patterns for cultural content, meaning and attitudes[1]. In higher education, especially in the Information Systems Study Program, the Cryptography course is one of the popular compulsory subjects among students, due to the high demand from companies and the industrial market for people who have expertise in this field. Various studies have been conducted with a focus on helping students in cryptography learning activities by using various learning methods and tools[2]. 
In the Cryptography course, students are required to have competence in designing and designing complex Security System [2]-[5]. In addition, students are expected to be able to build an understanding of network components and how they can be integrated to produce a complete system. Students are also expected to be able to compromise with network users in this case the company or industry to produce a system that suits user needs and balance it with the company's targeted budget.[3], the ability to perform data and network analysis and control network flows [6] and able to keep up with developments in network technology[7]

Based on the literature review, some of the obstacles that cause the lack of competence in Network Design and Management courses are the unavailability of a laboratory that can be used by students in simulating network design and management activities due to the high cost of equipment and maintenance that must be borne by universities.[8]. On the other hand, industry demands graduates who have the knowledge and ability to design networks in the real world[2]-[4] and have practice so that they are able to relate theory to the situation in the field [9]-[11].

Another problem faced in this Cryptography course is the limited time for face-to-face meetings in class/classroom learning activities while the cryptography material is very broad and complex so it is not possible to combine learning activities with practical activities at once. [11], [12]. Students' motivation is still low in studying cryptography material so that students feel bored with learning activities[5], [13].

Xiaomey Yu [14]based on the results of his research also stated that many students complained that they spent a lot of time reading learning materials and were frustrated with cryptography courses. If a demonstration based on a simulator is provided, students can understand the material and learn how to apply it in the real world.

Various solutions were given by previous researchers in solving these problems to improve student competence in Cryptography courses. Regarding the problem of the unavailability of laboratories that can be used by students in designing Security System, a visual laboratory design (V-lab) is made so that students can design and create simple networks visually.[7], [15]-[17]. With this V-lab, students get direct experience in designing and managing Security System so that they can compete in the real world of work.

The development of learning models using assistive media is also carried out by carrying out learning activities using learning applications such as Packet Tracer [2], [9], [13], VOIP app [18], ViRO app [19]. This learning application provides network simulation features that can be used by students in simulating the design and management of Security System so that students are expected to have experience in designing and designing Security System.

Many learning models are applied by teachers in achieving learning objectives such as the Blended Learning model. "Blended learning is a learning concept that integrates learning activities in traditional classrooms and e-learning elements in an effort to benefit from both forms of learning"[20]. On the other hand,[21]argued that "the blended learning model is a learning model that mixes traditional (face-to-face) learning with online learning, so that with this learning model, learning activities do not only occur in the classroom but also outside the classroom". While project based learning is a learning that focuses on concepts and facilitates students to investigate and determine a solution to the problems they face[22].

This study aims to measure the effectiveness of the project-based blended learning model, which develops a vocational education in collaboration with computer science. It is hoped that this learning model research can be applied in the learning process so that it can make students enthusiastic and motivated in learning.

\section{RESEARCH METHOD}

Based on the research objectives that have been described previously, this research is a research and development (Research and Development), design and development research tries to produce knowledge obtained from data that is systematically derived from what happened.

Table 1. Learning activities blended learning based on project

\begin{tabular}{cll}
\hline Week & \multicolumn{1}{c}{ Purpose } & \multicolumn{2}{c}{ Activity } \\
\hline 1 & Apperception & Lecturers deliver lecture contracts, codes of ethics, \\
& & assessments, lecture procedures with project-based \\
& blended learning models and the use of learning \\
& applications & Learning activities take place online (E-learning) using \\
$2-4$ & Retention of material & learning applications. Students can download \\
& materials/materials on the application and answer \\
& questions given by the lecturer and complete assignments \\
& and tests/quiz.
\end{tabular}




\begin{tabular}{|c|c|c|}
\hline Week & Purpose & Activity \\
\hline $5-6$ & $\begin{array}{l}\text { Network component assembly } \\
\text { practice }\end{array}$ & $\begin{array}{l}\text { The lecturer explains further the material that has been } \\
\text { learned at the online meeting and provides guidance in the } \\
\text { practical activities of cryptography components }\end{array}$ \\
\hline 7 & Midterm exam & $\begin{array}{l}\text { Lecturers give and test questions related to the material } \\
\text { that has been studied }\end{array}$ \\
\hline 8 & $\begin{array}{l}\text { Network design and design } \\
\text { practice and project task } \\
\text { description }\end{array}$ & $\begin{array}{l}\text { Lecturers provide tutorials on how to design and design } \\
\text { Security System which are then followed by students. } \\
\text { Lecturers form student groups for project assignments } \\
\text { The lecturer explains the implementation of project tasks } \\
\text { and how to prepare reports }\end{array}$ \\
\hline 9 & $\begin{array}{l}\text { Implementation of project } \\
\text { assignments by student groups }\end{array}$ & $\begin{array}{l}\text { Students make visits to companies to observe and analyze } \\
\text { the use of Security System. Lecturers will monitor these } \\
\text { activities using video conferencing applications. The } \\
\text { student group will make a project planning proposal. The } \\
\text { theme of each group's project assignments will be sent to } \\
\text { the lecturer using a learning application. }\end{array}$ \\
\hline $10-11$ & $\begin{array}{l}\text { Presentation of project planning } \\
\text { proposals and project work. }\end{array}$ & $\begin{array}{l}\text { Each group will present a project planning proposal } \\
\text { according to the theme that has been sent in the learning } \\
\text { application. Lecturers and students will discuss the project } \\
\text { planning proposal. The lecturer will validate the proposal } \\
\text { so that the student group can continue working on the } \\
\text { project } \\
\text { The lecturer will give time to work on the project, so that } \\
\text { each group of students can work on the project in groups } \\
\text { outside the classroom. Lecturers and students can discuss } \\
\text { using learning applications }\end{array}$ \\
\hline $12-15$ & $\begin{array}{l}\text { Project progress presentation and } \\
\text { project final report }\end{array}$ & $\begin{array}{l}\text { Student groups make project progress reports and present } \\
\text { the progress of the projects they are working on. } \\
\text { Lecturers and students can discuss the obstacles and } \\
\text { obstacles encountered in project work. } \\
\text { Student groups can complete the project according to the } \\
\text { results of the discussion and make a final project report. } \\
\text { Each group will present the final project report. } \\
\text { The lecturer guides the discussion. }\end{array}$ \\
\hline 16 & Final exams & $\begin{array}{l}\text { Lecturers give and test questions from the material that } \\
\text { has been studied }\end{array}$ \\
\hline
\end{tabular}

The effectiveness data in research on the development of project-based blended learning models in the Cryptography course were obtained from the analysis of several data collection instruments that have been tested for validity, including:

a. Analysis of student learning outcomes

1). Cognitive aspect learning outcomes

Assessment of learning outcomes from the cognitive aspect in general is the intellectual ability of students which can be grouped as Higher Order Thinking Levels, Middle Order Thinking Levels, Lower Order Thinking Levels. It consists of 6 levels revised by Anderson's, namely remembering, understanding, applying, analyzing, evaluating and creating.

2). Affective aspect learning outcomes

In assessing the affective aspects of students in the Cryptography course using a projectbased blended learning model consisting of several categories, namely receiving, responding, assessing or determining attitudes (valuing), organization (organization), characteristics/formation of lifestyle (characterization by a value or value complex)

3). Psychomotor aspect learning outcomes Learning outcomes in psychomotor aspects are abilities related to muscle and physical activities. EJ Simpson's (1972) suggests that the psychomotor aspect consists of 7 levels of learning objectives such as origination (new movement patterns/creativity), adaptation 
(modifies for special problems), complex over response (skillful performance acts of complex), mechanism (performs simple acts well), guided response (performs as demonstrated), set (relates cues/knows), perception (awareness of sensory stimulus). Psychomotor learning outcomes in this study started from students understanding the material, practicing the material to project assignments and completing the final project report.

The score of student learning outcomes obtained after using the project-based blended learning model was analyzed to see the level of achievement of student learning outcomes and each student's score was converted into a value with a range of 0-100 with the following categories:

Table 2. Category Of Student Learning Outcomes Assessment

\begin{tabular}{ccc}
\hline No & Achievement Level & Criteria \\
\hline 1 & $90-100$ & Very good \\
2 & $80-89$ & Well \\
3 & $65-79$ & Enough \\
4 & $55-64$ & Not enough \\
5 & $0-54$ & Not pass \\
\hline
\end{tabular}

\section{RESULT AND DISCUSSION}

Syntax is a stage or steps in learning. Syntax includes the main components that make up the model that describes how the model proceeds. The syntax used is:

1. Apperception

2. Understanding of the material (online learning)

3. Network component practice activities

4. Surmative evaluation

5. Network design practice and project task description

6. Company visits (project assignments)

7. Presentation of project proposals and project work

8. Project progress presentation and project final report

9. Surmative evaluation

The development of the learning model carried out in this study resulted in 9 (nine) syntaxes consisting of 1) Apperception, 2) Material Understanding (E-learning), 3) Network component practice activities, 4) Surmative evaluation, 5) Network design practice and explanations. project assignments, 6) Project activities (company visits), 7) Presentation of project proposals and project work, 8) Presentation of project progress and project final reports, 9) Surmative evaluation. The assessment of construct validation in the developed model is assessed from 5 (five) indicators, namely model syntax, social system, reaction principle, support system as well as instructional and accompaniment impacts. The assessment instrument for the developed model can be seen in appendix 8, while the results of the validator's assessment of the developed model can be seen in table 3 below : :

Table 3. Syntax validation results of project-based blended learning models

\begin{tabular}{lll}
\hline Syntax & Aiken's V & Information \\
\hline 1 & 0.80 & Valid \\
2 & 0.78 & Valid \\
3 & 0.80 & Valid \\
4 & 0.82 & Valid \\
5 & 0.80 & Valid \\
6 & 0.79 & Valid \\
7 & 0.80 & Valid \\
8 & 0.81 & Valid \\
9 & 0.80 & Valid \\
\hline
\end{tabular}

The results of the validation of the experts on the model developed from the calculation of the Likert Scale of each syntax obtained an average value of Aiken's V 0.80 with a value range of $0.78-0.82$, where for the range of values 0.667 can be interpreted as a high enough coefficient so that it can categorized as valid are in the valid category. In addition to calculating the Aiken's value, for the validation of this model, calculations were also carried out using the LISREL 8.8 software program.

The overall model assessment can be obtained based on the model fit (Goodness of Fit Statistics) generated by LISREL. The most common model accuracy index is the Chi-Square . value[23]. To assess the fit of the model, the Chi-Square value is not significant ( $\mathrm{p}$-value $>0.05$ ) because these results indicate that 
there is no difference between the model and the data.[23]. In addition, it is also seen from the loading factor value, which is the large correlation between the indicator and its latent construct. The reference weight factor of 0.50 or more is considered to have strong enough validation to explain the latent construct ([24]. The results of the test analysis of the syntax validation of the project-based blended learning model can be seen in Figure 4.6.

Based on the test results using LISREL 8.8 in Figure 4.6, it can be seen that the p-value obtained is 0.63670. This means that the p-value generated from the project-based blended learning model syntax test is $>0.05$, while the RMSEA value generated is $0.000(\leq 0.05)$ so it can be stated that the project-based blended learning model has met the criteria for goodness of fit models and its validity is categorized as fit or valid.

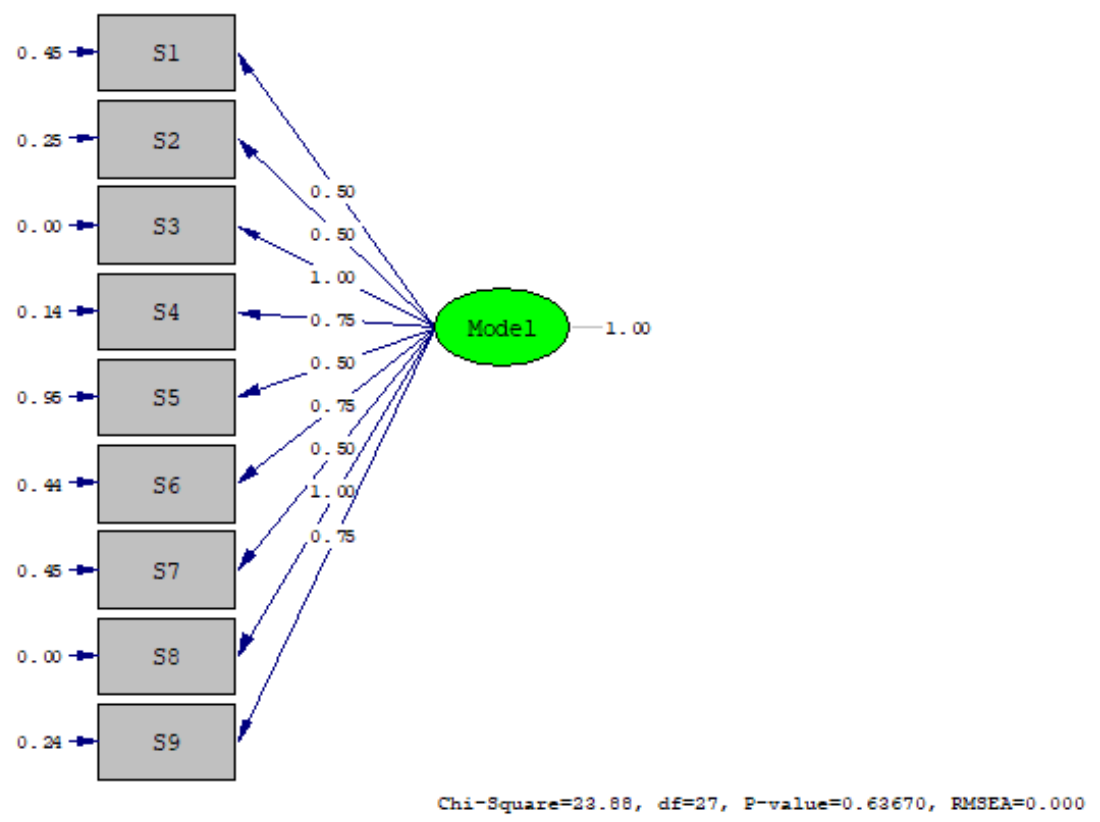

Figure 1, Results of Project-Based Blended Learning Model Validation Analysis

\subsection{Summative Evaluation}

Before conducting the summative evaluation, a pretest was conducted to determine the initial abilities of the students. This pretest was conducted with the aim of knowing that the test subjects had the same abilities and competencies and came from the same sample. The test questions were given to the control class and the experimental class. The results of the cognitive test of students in both classes to assess the initial abilities of these students were analyzed using IBM SPSS Statistics 21. The analysis carried out included homogeneity test, normality test and t test.

The test questions made were 50 items and then analyzed and obtained questions that could really be used to measure students' abilities. From the results of the analysis of the questions, namely the validity of the items, the difficulty index and the differentiating power of the questions which can be seen in appendix 41. 40 items were obtained that can be used with a fairly high reliability value of 0.45 which can be seen in appendix 42. Trial test questions which is used to assess student abilities can be seen in appendix 43 and student cognitive learning outcomes with project-based blended learning models in Cryptography courses can be seen in appendix 44 .

The learning outcomes (experimental class) are then compared with the learning outcomes of classes that follow lectures that do not use learning tools developed based on the principles of project-based blended learning models (control class). It aims to see whether the project-based blended learning model has an effect on student cognitive learning outcomes. The learning outcomes of the control class and the experimental class (posttest) can be seen in appendix 45 .

The t-test was used to see the level of difference in learning outcomes between the experimental class and the control class in this study. Before the t-test was carried out, the analysis requirements test was carried out, namely normality and homogeneity tests. The results of the t-test can be presented as follows: 


\section{Normality Test}

Normality test was performed using SPSS with Kolmogorov Smirnov statistic with a significant level of $\mathrm{a}=0.05$. The test results can be seen in the table below:

Table 4. Posttest normality test for control class and experimental class

Tests of Normality

\begin{tabular}{|l|l|r|r|r|r|r|r|}
\hline & \multirow{2}{*}{} & \multirow{2}{*}{ CLASS } & \multicolumn{3}{|c|}{ Kolmogorov-Smirnova } & \multicolumn{3}{|c|}{ Shapiro-Wilk } \\
\cline { 3 - 8 } & Statistic & \multicolumn{1}{c|}{ df } & Sig. & Statistic & \multicolumn{1}{c|}{ df } & Sig. \\
\hline LEARNING & EXPERIMENT &, 137 & 26 &, $200^{*}$ &, 947 & 26 &, 197 \\
OUTCOMES & CLASS & & & & & & \\
& CONTROL CLASS &, 171 & 24 &, 068 &, 942 & 24 &, 176 \\
\hline
\end{tabular}

*. This is a lower bound of the true significance.

a. Lilliefors Significance Correction

From the SPSS results presented in table 4.35 , it can be seen:

- For the experimental class, the sig value is $0.200 / 0.197>0.05$, which means the data is normally distributed.

- For the control class, the sig value is $0.068 / 0.176>0.05$, which means the data is normally distributed.

- So it can be concluded that the two data are normally distributed.

\section{Homogeneity Test}

The homogeneity test was carried out on the value of student learning outcomes using the Levene test with SPSS software with the data criteria being said to be homogeneous if the significance level was greater than 0.05. The test results can be seen in the table below:

Table 5. Homogeneity test posttest experimental class and control class

Test of Homogeneity of Variances

LEARNING OUTCOMES

\begin{tabular}{|c|c|c|c|}
\hline Levene Statistic & $\mathrm{df1}$ & $\mathrm{df2}$ & Sig. \\
\hline 1,495 & 1 & 48 & ,227 \\
\hline
\end{tabular}

From the SPSS results presented in table 4.36 above, it can be seen that the sig value is $0.227>0.05$, which means that the data has the same variance or is homogeneous.

\section{Test}

The t-test carried out is a two-mean independent test. The t-test was performed using SPSS software with a significant level of $\mathrm{a}=0.05$. The test results can be seen in the table below:

Table 6. T-test posttest experimental class and control

\begin{tabular}{|c|c|c|c|c|c|c|c|c|c|c|}
\hline \multicolumn{11}{|c|}{ Independent Samples Test } \\
\hline & & \multicolumn{2}{|c|}{$\begin{array}{l}\text { Levene's Test for Equality of } \\
\text { Variances }\end{array}$} & \multicolumn{7}{|c|}{ t-test for Equality of Means } \\
\hline & & \multirow[b]{2}{*}{$\mathrm{F}$} & \multirow[b]{2}{*}{ Sig. } & \multirow[b]{2}{*}{$t$} & \multirow[b]{2}{*}{ df } & \multirow[b]{2}{*}{ Sig. (2-tailed) } & \multirow{2}{*}{$\begin{array}{c}\text { Mean } \\
\text { Difference }\end{array}$} & \multirow{2}{*}{$\begin{array}{l}\text { Std. Error } \\
\text { Difference }\end{array}$} & \multicolumn{2}{|c|}{$\begin{array}{l}95 \% \text { Confidence Interval of the } \\
\text { Difference }\end{array}$} \\
\hline & & & & & & & & & Lower & Upper \\
\hline HASIL BELAJAR & $\begin{array}{l}\text { Equal variances } \\
\text { assumed }\end{array}$ & \multirow[t]{2}{*}{1,495} & \multirow[t]{2}{*}{,227 } & 2,950 & 48 &, 005 & 6,28205 & 2,12969 & 2,00003 & 10,56408 \\
\hline & $\begin{array}{l}\text { Equal variances not } \\
\text { assumed }\end{array}$ & & & 2,906 & 40,100 &, 006 & 6,28205 & 2,16192 & 1,91299 & 10,65111 \\
\hline
\end{tabular}

From the SPSS results presented in table 4.37, it can be seen that the equal variances assumed (homogeneous sample) has a sig value of $0.005<0.05$, which means that there is a significant difference in learning outcomes between the control class and the experimental class. So it can be concluded that there are differences in learning outcomes between students who use the modelblended learning project-based compared to students who did not use the project-based blended learning model in Cryptography courses. 


\subsection{Discussion}

The development of this model is carried out to provide solutions to problems encountered in learning activities for network design and management courses. Based on some literature that discusses the problems in these courses, almost all of them state that the basic problem faced in achieving learning competencies is the lack of abilities/skills possessed by students in the field of Security System so that students cannot compete in the work industry in the industrial era 4.0.

One of the reasons for this lack of abilities/skills possessed by students is that students are only given theoretical mastery without being accompanied by practical cryptography design activities. Of course, this greatly affects the lack of practical experience of students in learning activities in this course.

In accordance with the needs of research based on the Puslitjaknov stage, the authors carried out the following stages of research: 1). Analysis, 2) Design, 3). Expert validation and revision, 4). Trial and revision and 5). Implementation.

\section{Analysis}

The analysis activity is the first step taken in the development of this learning model. At this stage, a literature study is carried out and a needs analysis of the learning model in the design and management of cryptography courses is carried out. Needs analysis is carried out to see deficiencies or problems that have occurred in learning activities so far that have been the cause of not achieving learning objectives and competencies.

To see the learning needs in the Cryptography course, the researchers designed a needs analysis questionnaire to assess the extent to which this model can be used in learning activities. The questionnaire contains 33 questions related to learning activities and learning achievement. A total of 56 students were asked to fill out a questionnaire related to the current conditions in learning activities and the expected priorities in learning activities.

Based on the needs questionnaire filled out by these students, the results of the analysis of the current condition of learning activities are in the range of 2.00 to 3.50 . Of the 33 question items given, there are several aspects that have a low value category. Meanwhile, students' priorities/needs for the learning process of Cryptography have high expectations with an average score of 4.64 in the category of very much needed.

When compared as a whole, the comparison of current conditions with student needs/priorities towards learning activities is illustrated by the diagram in Figure 4.4. The average result of student assessment of the current condition is 2.80 and the average student assessment of priority/needs for learning activities is 4.64. From the results of the needs analysis assessment, it is clear that the current state of the lecture conditions is far below the needs/priorities in learning activities so that it is necessary to do renewal in learning activities.

\section{Design}

The second stage in the learning model development activities that the researcher designed is the design stage. At this stage the researcher designs and develops a project-based blended learning model which includes 5 important aspects according to[25] that is

a. Syntax, describes the model structure or sequence of steps included in the model organization.

b. Social system, describes the interaction between teachers and students, as well as students with students.

c. The principle of reaction describes the interaction between students and teachers, lecturers and students, as well as educators and students.

d. The support system is a necessary support condition for the successful implementation of the model.

e. Instructional impact and accompaniment impact are effects or impacts that can be observed or not in the learning process.

Learning activities are supported by the use of the Google Classroom learning application and the Jitsi Meet application. This designed learning model consists of 9 (nine) syntax learning activities, namely;

a. Syntax 1 (meeting 1): introduction of courses and objectives to be achieved, introduction of learning models and methods.

b. Syntax 2 (meetings 2-4): online learning activities using Google Classroom and the Jitsi Meet application (material understanding).

c. Syntax 3 (meeting 5-6): practical activities for assembling cryptography components.

d. Syntax 4 (meeting 7): Mid-Semester Exam.

e. Syntax 5 (meeting 8) : practical activities for designing Security System and project assignments.

f. Syntax 6 (meeting 9): student field visits to companies or agencies to carry out project assignments and make project proposals. 
g. Syntax 7 (meetings 10-11): Presentation of project proposals and reports on the progress of projects carried out.

h. Syntax 8 (meeting 12-15); project work and completion and the final project report and presentation of project results.

i. Syntax 9 (meeting 16): Final Semester Exam.

At this stage the researchers also designed the products produced in this study, namely model books, modules, lesson plans and guidebooks for using learning applications. Furthermore, the researchers also designed the questionnaires needed to assess the validity, practicality, and effectiveness of the model and the resulting product.

\section{Expert Validation and Revision}

Expert validation and revision is the third step in the development of the project-based blended learning model that has been developed along with the resulting product. In this activity, an assessment of the models and products that have been made is carried out to be assessed and discussed through Focus Group Discussions (FGD). The results of the FGD implementation are in the form of criticism and input from several experts which can be taken into consideration to revise the design of the developed model so that the resulting design can be valid, practical and effective.

After making revisions in accordance with the advice of experts, the next step is to validate the models and products developed with relevant experts. Validation carried out includes validation of the quality of research instrument content and validation of models and products including model books, teaching guides, teaching modules and application usage guidebooks.

The validation of the quality of the instrument content in this study consisted of needs analysis instruments, model and product instruments and practical instruments. The quality of the instrument in this study was validated by 3 relevant experts. The results of the validation of the overall quality of the research instrument are in Aiken's average value of 0.80 to 0.90 . Aiken's mean value can be interpreted as a high enough coefficient so that its validity can be categorized in the "valid" category.

Validation of the models and products produced is also carried out by relevant experts, where in this study there were 5 experts involved in testing the validity of models and products. Model and product validation includes project-based blended learning model syntax validation, model book validation, teaching guide validation, teaching product validation and learning application usage guide book validation. The results of the validity test on the developed models and products are described as follows:

a. Validation results on the development of project-based blended learning models

The validation of the project-based blended learning model syntax construct was carried out using the LISREL 8.8 software program. The results obtained with this test have met the criteria for the goodness of fit models where the p-value generated is 0.63670 . This means that the resulting p-value is 0.05 and the RMSEA value is 0.000 . So the construct validity is classified as fit or valid.

b. The results of the validation of the project-based blended learning model book

The results of the validation of the project-based blended learning model book based on 5 experts in terms of syntax, social systems, reaction principles, and support systems are in Aiken's V average value of $0.78-0.83$. The range of $\mathrm{V}$ numbers obtained is interpreted as a fairly high coefficient and is categorized as valid. It can be concluded that the model book that has been tested for validity is declared suitable for use in learning activities of Cryptography.

c. The results of the validation of the teaching guide.

The results of the validation of experts on the project-based blended learning model teaching guide in Cryptography courses, which consist of aspects of content components, content feasibility, RPS construction and language aspects are in Aiken's V average value of $0.78-0,80$. The range of the number $\mathrm{V}$ obtained is interpreted as a fairly high coefficient and is categorized as valid, so it can be concluded that the model book that has been tested for validity is declared suitable for use in Cryptography learning activities.

d. The results of the validation of the teaching module.

The results of expert validation of project-based blended learning teaching modules in Cryptography courses, which consist of material aspects, module appearance, module characteristics and module benefits are in Aiken's V average value of $0.80-0.88$. The range of the number $\mathrm{V}$ obtained is interpreted as a fairly high coefficient and is categorized as valid, so it can be concluded that the model book that has been tested for validity is declared suitable for use in Cryptography learning activities.

e. The results of the validation of the learning application usage guide

The results of the validation of the experts on the guide to the use of learning applications in the Cryptography course, which consists of aspects of content components, usage instructions, 
typography and language aspects are in A1ken's $V$ average value of $0.90-0.94$. The range of the number $\mathrm{V}$ obtained is interpreted as a fairly high coefficient and is categorized as valid, so it can be concluded that the model book that has been tested for validity is declared suitable for use in Cryptography learning activities.

\section{Trial and Revision}

After going through the validation stage, the next stage of the product developed is tested on the research object on a small scale. In this study, trials were carried out on 6 students, where at this stage a practical test of the teaching modules and learning media/applications was carried out.

Practical test of teaching modules and learning media by 6 students refers to the practicality category by [26]. The test results obtained after applying the teaching module for a small scale produce an average practicality percentage of $85.33 \%$. While the results of the practicality test of learning media produce a percentage of $90 \%$. The test results on this small scale meet the practical category, so these test results allow the application of the product to a wider sample.

\section{Implementation}

The last step in developing a project-based blended learning model according to Puslitjaknov's steps is to implement the developed model and product. Implementation can be carried out if all the products developed are valid and feasible to use. This implementation involves a larger number of samples.

The practicality test of the product developed was assessed by lecturers and students. Practicality tests by lecturers include practicality tests of project-based blended learning models, teaching guides and teaching modules. While the practicality test by students includes learning module tests and learning media/applications. The lecturers involved in the practicality test of the project-based blended learning model consisted of 5 lecturers who taught Cryptography courses, while the students involved in assessing the practicality in this study were students who joined the experimental class totaling 26 students.

The results of the practicality test of the project-based blended learning model by the lecturer produced an average practicality percentage of $83.33 \%$ so that it could be categorized as practical. The results of the practicality test for teaching modules have a practicality percentage value of $85.78 \%$ which is also categorized in the practical category, while the practicality value for teaching guides by lecturers produces a percentage of 84.28 which is also categorized as practical. From the three assessments of the practicality of the research product by the lecturer, it can be concluded that the product is feasible to use because it meets the expected category.

To test the practicality of product development of project-based blended learning models by students, it includes practicality tests of learning modules and learning media/applications. After the research model and product were implemented in the experimental class, the practicality of the research product was measured by distributing questionnaires and asking students who were involved in learning in the experimental class to fill out the questionnaire. The results of the practicality test of teaching modules have a percentage value of $88.35 \%$ while the practicality test for learning media/applications has a percentage value of $90.21 \%$, so that the results of the practicality test of teaching modules and learning media/applications can be categorized in the practical category.

Another test carried out is the model's effectiveness test. The test was carried out through formative tests and summative tests. The formative test aims to assess performance and attitudes (psychomotor and affective). This test is given according to the syntax stages of the project-based blended learning model, while the summative test aims to measure students' cognitive abilities before and after using the projectbased blended learning model. This test is given in the form of multiple choice questions which are first tested for validity, level of difficulty and differentiating power of questions.

The results of the effectiveness test of this study stated that there was a significant difference in the learning outcomes of the control class and the experimental class. Learning outcomes in the experimental class showed increased results when compared to the control class. Previously, a pretest was conducted to see that students in both classes had the same ability and understanding (homogeneous). It can be concluded that the project-based blended learning model developed has succeeded in increasing the ability and competence in learning in Cryptography courses to be more effective. 


\section{CONCLUSION}

Based on the results and discussions that have been presented and in accordance with the expected research objectives related to the development of project-based blended learning models in Cryptography courses, it can be concluded:

1. This research has succeeded in developing a project-based blended learning model as a learning model in Cryptography courses with a development model adopted from the Center for Policy Research and Innovation.

2. The project-based blended learning model that was developed produces products in the form of model books, teaching guides, teaching modules and guidebooks for the use of learning applications that are used to support learning activities.

3. The project-based blended learning model developed along with the resulting product has been tested to be valid, practical and effective. The validity test involves experts who are competent in their fields to assess the validity of research instruments and the validity of research products. For the practicality test, it involves lecturers who are in charge of courses and students who are members of the experimental class in the course of Cryptography. Meanwhile, the effectiveness test was carried out by involving the control class and the experimental class to see differences in student learning outcomes after using the project-based blended learning model.

2. The achievement of student competence in the Cryptography course after implementing the projectbased blended learning model has increased in terms of cognitive, psychomotor and effective. In addition, by implementing the project-based blended learning model, students are also equipped with experience and knowledge about the application of science, especially the design and management of Security System in the world of work by conducting visits by students to companies/industry.

\section{ACKNOWLEDGEMENT}

The researcher would like to thank to STMIK Triguna Dharama.

\section{REFERENCES}

[1] T. Voronchenko, T. Klimenko, and I. Kostina, "Learning to Live in a Global World: Project-Based Learning in Multicultural Student Groups as a Pedagogy of Tolerance Strategy," Procedia - Soc. Behav. Sci., vol. 191, pp. 1489-1495, 2015, doi: 10.1016/j.sbspro.2015.04.472.

[2] H. M. Yongbin Zhang, Ronghua Liang, "Teaching innovation in Computer Netrwork Course for Undergraduates Students With PAcket Tracer," Int. Conf. Futur. Comput. Support. Educ., vol. 2, pp. 504-510, 2012, doi: 10.1016/j.ieri.2012.06.124.

[3] N. Linge and D. Parsons, "Problem - based learning as an effective tool for teaching computer network design Problem-Based Learning as an Effective Tool for Teaching Computer Network Design," 2006.

[4] S. R. and L. C. D. H. Noel Davis capt and N. Through, "Teaching Computer Networks Through Modeling by," Electr. Eng. Comput. Sci., 1996.

[5] N. I. Sarkar, "Teaching Computer Networking Fundamentals Using Practical Laboratory Exercises," Annu. Conf. NACCQ, New Zealand, Junu 2000, pp. 1-22, 2000.

[6] J. Janitor, F. Jakab, and K. Kniewald, "Visual Learning Tools for Teaching / Learning Computer Networks Cisco Networking Academy and Packet Tracer,” pp. 351-355, 2010, doi: 10.1109/ICNS.2010.55.

[7] J. Pan, "Teaching Computer Networks in a Real Network The Technical Perspectives," SIGCSE10, pp. 133-137, 2010.

[8] J. Ning et al., "Spatiotemporal patterns and characteristics of land-use change in China during 20102015," J. Geogr. Sci., vol. 28, no. 5, pp. 547-562, 2018, doi: 10.1007/s11442-018-1490-0.

[9] W. F. Marti, U. W. Pooch, and J. A. Hamilton, "PACKET tracing: a new paradigm for teaching computer network courses," pp. 162-164, 1996.

[10] L. 1 P. and B. Davie, “Computer Networks : A Systems approach,” Networks Telecommun., pp. 1-6, 2008.

[11] R. K. C. Chang, "Teaching Computer Networking with the Help of Personal Computer Networks," pp. 208-212, 2004.

[12] Z. Ran, "Exploration on the Key Issues of Practical Teaching Reform of Computer Network," vol.

Jurnal Teknologi dan Open Source, Vol. 4, No. 2, December 2021: 205 - 215 
17, pp. 1914-1919, 2012, do1: 10.1016/j.egypro.2012.02.332.

[13] M. Syahrizad, A. Zamzuri, and M. Ali, "Survey on the Challenges Faced by the Lecturers in Using Packet Tracer Simulation in Computer Networking Course," Procedia - Soc. Behav. Sci., vol. 131, pp. 11-15, 2014, doi: 10.1016/j.sbspro.2014.04.070.

[14] X. Yu, "The Construction and Application of Simulation Teaching System for Computer Network Curricula," IEEE, vol. 07, pp. 524-527, 2007.

[15] N. Jovanovic, R. Popovic, S. Markovic, and Z. Jovanovic, "Web Laboratory for Computer Network," pp. 1-10, 2010, doi: 10.1002/cae.20417.

[16] A. Kayssi, S. Sharafeddine, and H. Karaki, "Computer-Based Laboratory for Data Communications and Computer Networking,” pp. 84-97, 2003, doi: 10.1002/cae.20002.

[17] D. Liu, P. Valdiviezo-díaz, G. Riofrio, and Y. Sun, "Integration of Virtual Labs into Science Elearning," Procedia - Procedia Comput. Sci., vol. 75, no. Vare, pp. 95-102, 2015, doi: 10.1016/j.procs.2015.12.224.

[18] S. S. Kulkarni, "USING VOIP AS A COMMON FRAMEWORK FOR TEACHING A SECOND COURSE IN COMPUTER NETWORKS.” 2007.

[19] P. Sege, M. Kubina, and P. Palúch, "ViRo - the online tool for the networking education," vol. 174, pp. 3788-3796, 2015, doi: 10.1016/j.sbspro.2015.01.1114.

[20] A. H. Aldholay, Z. Abdullah, T. Ramayah, O. Isaac, and A. M. Mutahar, "Online learning usage and performance among students within public universities in Yemen," Int. J. Serv. Stand., vol. 12, no. 2, pp. 163-179, 2018, doi: 10.1504/IJSS.2018.091842.

[21] B. Collis and J. Moonen, "Flexible Learning in a Digital World," Open Learn. J. Open, Distance eLearning, vol. 17, no. 3, pp. 217-230, Sep. 2002, doi: 10.1080/0268051022000048228.

[22] I. W. Santyasa, "Validasi Dan Implementasi Model-Model Student Centered Learning Untuk Meningkatkan Penalaran Dan Karakter Siswa Sekolah Menengah Atas," JPI (Jurnal Pendidik. Indones., vol. 4, no. 1, pp. 512-527, 2015, doi: 10.23887/jpi-undiksha.v4i1.4890.

[23] D. S. K. G. Jöreskog, LISREL 8: Structural Equation Modeling with the SIMPLIS Command Language. North Licoin Avenue, 1993.

[24] H. J. Snippert et al., "Lgr6 marks stem cells in the hair follicle that generate all cell lineages of the skin," Science (80-. )., vol. 327, no. 5971, pp. 1385-1389, 2010, doi: 10.1126/science.1184733.

[25] "BEYOND," vol. 36, no. 6, p. 2015, 2015.

[26] D. Purwanto, "Analisis Penilaian Tingkat Kesehatan Bank Pada Bmt Ums Dengan Metode Camel," 2007. 